Brit. J. vener. Dis. (1962), 38, 134

\title{
GONORRHOEA IN THE CITY OF MANCHESTER, 1951-1961*
}

\author{
BY \\ S. M. LAIRD \\ Regional Adviser in Venereology, Manchester Regional Hospital Board; \\ Director, St. Luke's Clinic and V.D. Department, Royal Infirmary, Manchester
}

The incidence of gonorrhoea fell sharply and steadily from its post-war peak in 1946 until 1951; from 1951 to 1955 no special feature was obvious, and since 1955 the trend has been steadily upwards. These trends in the gonorrhoea figures for the V.D. clinics of England and Wales are closely mirrored by those of the Manchester clinics (Table I).

The decrease in Manchester in the number of male infections with gonorrhoea during late 1959 and in 1960 was attributed (Laird, 1961) to the greater control of street prostitution which followed the implementation in August, 1959, of the Street Offences Act.

In Manchester between 1955 and 1961, gonorrhoea increased by 43 per cent. (from 1,345 to 1,925 ) in males and by 57 per cent. (from 365 to 574) in females. These large increases, occurring during a period of peace and plenty, must be due to new epidemiological factors, and the study reported below was undertaken to define these new features.

\section{Gonorrhoea in Males}

Excluding seafarers seen at the Seamen's Dispensary, male infections with gonorrhoea, diagnosed in the V.D. clinics of the City of Manchester during the years 1951, 1955, 1959, and 1961, and classified according to certain age groups (Table II, opposite), show that:

(a) The actual numbers and relative percentages in each age group were very similar in 1951 and 1955;

(b) While the figures for 1959 and 1961 show an absolute increase in all age groups, the relative increases are greater in the younger age groups, i.e. in those aged 14-19 years and 20-24 years;

(c) The actual numbers of cases in youths under 18 years are too small to reveal any trend;

* Received for publication May 21, 1962.
TABLE I

INFECTIONS WITH GONORRHOEA DIAGNOSED IN THE TREATMENT CENTRES OF ENGLAND AND WALES AND THE CITY OF MANCHESTER

\begin{tabular}{c|c|c|c|c|c|c}
\hline \multirow{2}{*}{ Year } & \multicolumn{2}{|c|}{ England and Wales* } & \multicolumn{2}{|c|}{ City of Manchester } \\
\cline { 2 - 6 } & Males & Females & Total & Males & Females & Total \\
\hline 1946 & 36,912 & 10,431 & 47,343 & 2,854 & 693 & 3,547 \\
\hline 1947 & 29,647 & 7,019 & 36,666 & 2,409 & 495 & 2,904 \\
\hline 1948 & 25,006 & 5,306 & 30,312 & 2,080 & 368 & 2,448 \\
\hline 1949 & 20,366 & 4,121 & 24,487 & 1,644 & 361 & 2,005 \\
\hline 1950 & 17,007 & 3,497 & 20,504 & 1,278 & 242 & 1,520 \\
\hline 1951 & 14,975 & 3,089 & 18,064 & 1,266 & 248 & 1,514 \\
\hline 1952 & 15,510 & 3,585 & 19,095 & 1,475 & 444 & 1,919 \\
\hline 1953 & 15,242 & 4,021 & 19,263 & 1,214 & 348 & 1,562 \\
\hline 1954 & 13,962 & 3,574 & 17,536 & 1,175 & 314 & 1,489 \\
\hline 1955 & 14,079 & 3,766 & 17,845 & 1,345 & 365 & 1,710 \\
\hline 1956 & 16,377 & 4,011 & 20,388 & 1,283 & 343 & 1,626 \\
\hline 1957 & 19,620 & 4,761 & 24,381 & 1,557 & 393 & 1,950 \\
\hline 1958 & 22,398 & 5,489 & 27,887 & 1,765 & 455 & 2,220 \\
\hline 1959 & 24,964 & 6,380 & 31,344 & 1,739 & 507 & 2,246 \\
\hline 1960 & 26,618 & 7,152 & 33,770 & 1,535 & 496 & 2,031 \\
\hline 1961 & $29,500 \dagger$ & $7,526 \dagger$ & $37,026 \dagger$ & 1,925 & 574 & 2,499 \\
\hline
\end{tabular}

* From the Reports of the Chief Medical Officer, Ministry of Health.

† Estimated totals from quarterly figures.

(d) The increases in those aged 18 and 19 years, in 1959 and 1961, are relatively large, although the actual numbers (70 in 1959 and 60 in 1961) are not alarming;

(e) The increase in the 20 to 24-year group is 66 per cent. (a mean of 305 for 1951 and 1955 compared with the mean of 507 for 1959 and 1961);

$(f)$ Patients aged 25 years and over show a 20 per cent. increase, which is small compared with that in the younger patients. 
TABLE II

MALE CASES OF GONORRHOEA IN MANCHESTER CLINICS (EXCEPT SEAMEN'S DISPENSARY)

\begin{tabular}{|c|c|c|c|c|c|c|c|c|}
\hline \multirow{2}{*}{$\begin{array}{c}\text { Age } \\
(\mathrm{yrs})\end{array}$} & \multicolumn{2}{|c|}{1951} & \multicolumn{2}{|c|}{1955} & \multicolumn{2}{|c|}{1959} & \multicolumn{2}{|c|}{1961} \\
\hline & No. & $\begin{array}{c}\text { Per } \\
\text { cent. }\end{array}$ & No. & $\begin{array}{l}\text { Per } \\
\text { cent. }\end{array}$ & No. & $\begin{array}{c}\text { Per } \\
\text { cent. }\end{array}$ & No. & $\begin{array}{c}\text { Per } \\
\text { cent. }\end{array}$ \\
\hline $\begin{array}{c}\text { Under } \\
14\end{array}$ & - & - & - & - & - & - & - & - \\
\hline 14 & - & - & - & - & - & - & - & - \\
\hline 15 & - & - & - & - & - & - & 2 & - \\
\hline 16 & 1 & - & 1 & - & 5 & - & 3 & - \\
\hline 17 & 6 & - & 3 & - & 5 & - & 6 & - \\
\hline 18 & 9 & - & 10 & - & 24 & - & 21 & - \\
\hline 19 & 13 & - & 11 & - & 46 & - & 39 & - \\
\hline $\begin{array}{c}\text { Total } \\
14 \text { to } 19\end{array}$ & 29 & $2 \cdot 2$ & 25 & $1 \cdot 9$ & 80 & $4 \cdot 7$ & 71 & $3 \cdot 8$ \\
\hline 20 to 24 & 331 & $24 \cdot 8$ & 279 & $21 \cdot 1$ & 503 & $29 \cdot 4$ & 512 & $27 \cdot 5$ \\
\hline $\begin{array}{l}25 \text { and } \\
\text { Over }\end{array}$ & 974 & $73 \cdot 0$ & 1,020 & $77 \cdot 0$ & 1,128 & $65 \cdot 9$ & 1,277 & $68 \cdot 7$ \\
\hline Total & 1,334 & 100 & 1,324 & 100 & 1,711 & 100 & 1,860 & 100 \\
\hline
\end{tabular}

Table III shows the age groups of male patients with gonorrhoea who were born in the United Kingdom. It will be noted that the numbers of U.K. patients with gonorrhoea were smaller in 1959 and 1961 and considerably below the 1951 figure. This reduction applied to all U.K. patients, except those in the 14 to 19 -year group which showed a relatively large rise although the actual number of cases (59 in 1959 and 39 in 1961) was small.

Nationality of Male Patients.-Detailed data of nationality of male patients are not available for 1951 but are shown as percentages of total cases in each of three age groups for 1955, 1959, and 1961 in Table IV. Comparing the percentages for 1961 with those for 1955 it will be seen that:
TABLE III

MALE GONORRHOEA CASES BORN IN U.K.

\begin{tabular}{|c|c|c|c|c|c|c|c|c|}
\hline \multirow{2}{*}{$\begin{array}{c}\text { Age } \\
\text { (yrs) }\end{array}$} & \multicolumn{2}{|c|}{1951} & \multicolumn{2}{|c|}{1955} & \multicolumn{2}{|c|}{1959} & \multicolumn{2}{|c|}{1961} \\
\hline & No. & $\begin{array}{c}\text { Per } \\
\text { cent. }\end{array}$ & No. & $\begin{array}{l}\text { Per } \\
\text { cent. }\end{array}$ & No. & $\begin{array}{c}\text { Per } \\
\text { cent. }\end{array}$ & No. & $\begin{array}{l}\text { Per } \\
\text { cent. }\end{array}$ \\
\hline $\begin{array}{c}\text { Under } \\
14\end{array}$ & - & - & - & - & - & - & $1^{*}$ & - \\
\hline 14 & - & - & - & - & - & - & - & - \\
\hline 15 & - & - & - & - & - & - & 2 & - \\
\hline 16 & 1 & - & 1 & - & 5 & - & 3 & - \\
\hline 17 & 4 & - & 3 & - & 5 & - & 3 & - \\
\hline 18 & 5 & - & 8 & - & 20 & - & 14 & - \\
\hline 19 & 8 & - & 7 & - & 29 & - & 17 & - \\
\hline $\begin{array}{c}\text { Total } \\
14 \text { to } 19\end{array}$ & 18 & $1 \cdot 5$ & 19 & $2 \cdot 1$ & 59 & $7 \cdot 3$ & 39 & $4 \cdot 7$ \\
\hline 20 to 24 & 289 & $23 \cdot 6$ & 251 & $27 \cdot 7$ & 233 & $28 \cdot 9$ & 237 & $27 \cdot 6$ \\
\hline $\begin{array}{l}25 \text { and } \\
\text { Over }\end{array}$ & 918 & $74 \cdot 9$ & 637 & $70 \cdot 2$ & 515 & $63 \cdot 8$ & 581 & $67 \cdot 7$ \\
\hline Total & 1,225 & 100 & 907 & 100 & 807 & 100 & 858 & 100 \\
\hline
\end{tabular}

* 13-yr-old schoolboy with venereal gonorrhoea.

(a) Male patients born in U.K. were considerably reduced in all age groups.

(b) Male patients born in Eire increased in the teenage and 20 to 24-year groups.

(c) Male patients born in the British West Indies increased markedly in all age groups; in the teenage group they increased from nil in 1955 to almost one-fifth of the total in 1961.

(d) Male patients born in West Africa generally represented only a small percentage of the total patients; they did not figure in the teenage group but made a larger contribution in 1961 to the 20 to 24-year group.

(e) Other nationals made a small contribution to all age groups, but in the teenage group their contribution was little smaller than that of the West Indians.

TABLE IV

PERCENTAGE MALE GONORRHOEA IN MANCHESTER CLINICS, BY AGE GROUP AND COUNTRY OF ORIGIN

\begin{tabular}{|c|c|c|c|c|c|c|c|c|c|c|c|c|c|}
\hline \multirow{2}{*}{ Year $\cdots$} & \multirow{2}{*}{$\cdots$} & \multirow{2}{*}{$\cdots$} & \multirow{2}{*}{. } & \multirow{2}{*}{$\begin{array}{l}\cdots \\
\cdots\end{array}$} & \multicolumn{3}{|c|}{$1955^{*}$} & \multicolumn{3}{|c|}{1959} & \multicolumn{3}{|c|}{1961} \\
\hline & & & & & $14-19$ & $20-24$ & $\begin{array}{l}25 \text { and } \\
\text { Over }\end{array}$ & $14-19$ & $20-24$ & $\begin{array}{l}25 \text { and } \\
\text { Over }\end{array}$ & $14-19$ & $20-24$ & $\begin{array}{c}25 \text { and } \\
\text { Over }\end{array}$ \\
\hline \multirow{5}{*}{ Country of Origin } & \multirow{5}{*}{.. } & U.K. . . & . & . & $68 \cdot 7$ & $84 \cdot 5$ & $53 \cdot 6$ & $72 \cdot 5$ & $46 \cdot 5$ & $45 \cdot 7$ & $54 \cdot 9$ & $46 \cdot 3$ & $45 \cdot 5$ \\
\hline & & Eire $\quad$. & . & . & $6 \cdot 3$ & $3 \cdot 9$ & $11 \cdot 3$ & $2 \cdot 5$ & $16 \cdot 7$ & $11 \cdot 1$ & $11 \cdot 3$ & $10 \cdot 2$ & $6 \cdot 7$ \\
\hline & & West Indies & . & $\ldots$ & - & $3 \cdot 3$ & $13 \cdot 0$ & $15 \cdot 0$ & $24 \cdot 8$ & $23 \cdot 6$ & $18 \cdot 3$ & $28 \cdot 7$ & $31 \cdot 1$ \\
\hline & & West Africa & .. & . & - & $3 \cdot 3$ & $14 \cdot 4$ & $2 \cdot 5$ & $2 \cdot 9$ & $9 \cdot 4$ & - & $10 \cdot 7$ & $7 \cdot 3$ \\
\hline & & Other & $\ldots$ & $\ldots$ & 25 & 5 & $7 \cdot 7$ & $7 \cdot 5$ & $9 \cdot 1$ & $10 \cdot 2$ & $15 \cdot 5$ & $4 \cdot 1$ & $9 \cdot 4$ \\
\hline \multirow{2}{*}{ Total } & \multirow[b]{2}{*}{$\cdots$} & No. & . & . & 16 & 180 & 753 & 80 & 503 & 1,128 & 71 & 512 & 1,277 \\
\hline & & Per cent. & $\ldots$ & $\ldots$ & 100 & 100 & 100 & 100 & 100 & 100 & 100 & 100 & 100 \\
\hline
\end{tabular}

* 1955 percentages calculated on figures from St. Luke's Clinic only. 


\section{Gonorrhoea in Females}

Excluding cases of gonococcal ophthalmia neonatorum and pre-pubertal vulvo-vaginitis, the numbers of female infections with gonorrhoea diagnosed during the years $1951,1955,1959$, and 1961 in all the V.D. clinics of the City of Manchester, classified by age, are shown in Table V. It will be seen that:

(a) The absolute numbers and relative percentages in each age group during 1951 and 1955 were essentially the same.

(b) The absolute numbers of females aged 25 years and over differed little in 1959 and 1961 as compared with the earlier years, but the relative percentages were reduced.

(c) In the 20 to 24-year group, the absolute numbers in 1959 and 1961 were about 50 per cent. greater than in 1951 and 1955.

(d) In the teenage group, the absolute numbers were similar in 1951 and 1955, two-and-a-half times greater in 1959, and three times greater in 1961. Patients aged 16 years and under appeared for the first time in 1959 and 1961, but were still exceptional, forming only about 2 per cent. of the total female cases.

(e) As the absolute numbers in each of the three main age groups for 1961 showed appreciable increases on the 1959 figures, there is no indication in these data from Manchester that the rising trend of gonorrhoea in females is abating.

TABLE V

ALL MANCHESTER CLINICS: FEMALE GONORRHOEA

\begin{tabular}{|c|c|c|c|c|c|c|c|c|}
\hline \multirow{2}{*}{$\begin{array}{c}\text { Age } \\
\text { (yrs) }\end{array}$} & \multicolumn{2}{|c|}{$1951^{*}$} & \multicolumn{2}{|c|}{1955} & \multicolumn{2}{|c|}{1959} & \multicolumn{2}{|c|}{1961} \\
\hline & No. & $\begin{array}{l}\text { Per } \\
\text { cent. }\end{array}$ & No. & $\begin{array}{c}\text { Per } \\
\text { cent. }\end{array}$ & No. & $\begin{array}{c}\text { Per } \\
\text { cent. }\end{array}$ & No. & \begin{tabular}{|l} 
Per \\
cent.
\end{tabular} \\
\hline 14 & - & - & - & - & - & - & 3 & 0.6 \\
\hline 15 & - & - & - & - & 2 & 0.4 & - & - \\
\hline 16 & - & - & - & - & 6 & $1 \cdot 3$ & 8 & 1.5 \\
\hline 17 & 7 & $2 \cdot 3$ & 4 & $1 \cdot 5$ & 19 & $4 \cdot 2$ & 24 & $4 \cdot 4$ \\
\hline 18 & 11 & $3 \cdot 5$ & 11 & $3 \cdot 2$ & 35 & $7 \cdot 7$ & 34 & $6 \cdot 3$ \\
\hline 19 & 23 & $7 \cdot 3$ & 29 & $8 \cdot 5$ & 39 & $8 \cdot 5$ & 57 & $10 \cdot 5$ \\
\hline $\begin{array}{c}\text { Total } \\
14 \text { to } 19\end{array}$ & 41 & $13 \cdot 1$ & 44 & $13 \cdot 2$ & 101 & $22 \cdot 1$ & 126 & $23 \cdot 3$ \\
\hline 20 to 24 & 122 & $38 \cdot 8$ & 114 & $33 \cdot 4$ & 183 & $40 \cdot 0$ & 198 & $36 \cdot 6$ \\
\hline $\begin{array}{l}25 \text { and } \\
\text { Over }\end{array}$ & 151 & $48 \cdot 1$ & 183 & $53 \cdot 4$ & 173 & $37 \cdot 9$ & 217 & $40 \cdot 1$ \\
\hline Total & 314 & 100 & 341 & 100 & 457 & 100 & 541 & 100 \\
\hline
\end{tabular}

* Royal Infirmary clinic figures included in the 1951 totals are for 1952.

\section{Discussion}

\section{Gonorrhoea in the Male}

Diagnosis.-The criteria of diagnosis of gonorrhoea in the male-the presence of urethritis and the finding of pus cells with intracellular, Gramnegative diplococci-remained unchanged during the period of this study and thus, in this respect, the male figures for 1951, 1955, 1959, and 1961 are strictly comparable. Beginning in 1951, the V.D. clinics in England and Wales have been required to distinguish, in their annual statistical returns (Form V.D.(R) ) to the Ministry of Health, between gonococcal and non-gonococcal urethritis. It is possible that a few cases, originally gonococcal, have been classified as non-gonococcal urethritis because of self-medication or other preliminary treatment before attendance at the V.D. clinic, but such cases are insignificant numerically.

Re-infections. - The data presented in this study refer to infections diagnosed and not to individual patients treated. Thus the promiscuous individual may account for two or more separate infections in the annual total. Since 1955 this point has received strict attention in Manchester, but previously reinfection might have been treated without being recorded as such in the clinic statistics.

The distinction between recurrence of urethritis due to relapse arising from failure of treatment and that due to re-infection following successful therapy, whilst occasionally difficult, can commonly be made when the interval between clinical cure and recurrence exceeds two weeks and further exposure to infection is admitted. When the interval is shorter or when the patient claims that his symptoms never cleared after treatment, culture of the gonococcus and estimation of its sensitivity to penicillin may assist the distinction (Gjessing and Ödegaard, 1962). With this point, and the possibility of the diminished sensitivity of the gonococcus to penicillin, in mind, it has been our practice in Manchester in recent years, to carry out cultures and sensitivity tests in all cases in which urethritis persists, or soon returns, after penicillin treatment. Thus re-infections have been noted more accurately in 1959 and 1961 than in 1955 and still more so than in 1951.

This problem of the "repeater" is quantitatively significant (Chief Medical Officer's Report (1960) p. 59). At St. Luke's Clinic, Manchester, in 1959, 1,014 male patients were treated for 1,239 infections with gonorrhoea ( 22 per cent. "repeaters"). In 1961 at the same clinic, 1,165 patients were treated for 1,486 infections, i.e. 219 men (19 per cent.) were treated more than once in the same calendar year (Table VI, opposite). These 219 men accounted for 540 (36 per cent.) of the total of 1,486 infections treated.

Table VII shows that only 39 per cent. of these "repeaters" were born in the U.K. and that West 
TABLE VI

MALE "REPEATERS" AT ST. LUKE'S CLINIC, MANCHESTER, 1961

\begin{tabular}{|c|c|c|c|c|}
\hline \multicolumn{4}{|c|}{ Total number of gonorrhoea infections } & 1,486 \\
\hline \multicolumn{4}{|c|}{ Total number of male patients } & 1,165 \\
\hline \multicolumn{4}{|c|}{$\begin{array}{l}\text { Number of patients treated for more than } \\
\text { one infection in the same calendar year.. }\end{array}$} & 219 (19 per cent.) \\
\hline $\begin{array}{r}157 \text { for } 2 \text { infections } \\
40 \text { for } 3 \text { infections } \\
13 \text { for } 4 \text { infections } \\
5 \text { for } 5 \text { infections } \\
2 \text { for } 6 \text { infections } \\
1 \text { for } 8 \text { infections } \\
1 \text { for } 9 \text { infections }\end{array}$ & $\begin{array}{l}\cdots \\
\cdots \\
\cdots \\
\cdots \\
\cdots\end{array}$ & $\begin{array}{l}\cdots \\
\cdots \\
\cdots \\
\cdots \\
\cdots \\
\cdots\end{array}$ & $\begin{array}{l}\cdots \\
\cdots \\
\cdots \\
\cdots \\
\cdots \\
\cdots\end{array}$ & $\begin{array}{r}314 \\
120 \\
52 \\
25 \\
12 \\
8 \\
9\end{array}$ \\
\hline \multicolumn{4}{|c|}{219 (19 per cent. of total patients) . $\quad \ldots$} & $\begin{array}{l}540 \text { (36 per cent. of } \\
\text { total infections) }\end{array}$ \\
\hline
\end{tabular}

Indian patients (also 39 per cent.) provided almost twice as many "repeaters" as all other foreign nationals combined.

TABLE VII

ST. LUKE'S CLINIC, MANCHESTER. AGE GROUP AND COUNTRY OF ORIGIN OF MALE "REPEATERS" WITH GONORRHOEA, 1961

\begin{tabular}{|c|c|c|c|c|c|c|c|}
\hline \multirow{2}{*}{\multicolumn{3}{|c|}{ Country of Origin }} & \multicolumn{3}{|c|}{ Age (yrs) } & \multicolumn{2}{|c|}{ Total } \\
\hline & & & \multirow{2}{*}{$\begin{array}{c}\begin{array}{c}\text { Under } \\
20\end{array} \\
1\end{array}$} & \multirow{2}{*}{$\frac{20-24}{23}$} & \multirow{2}{*}{$\begin{array}{c}\begin{array}{c}25 \text { and } \\
\text { Over }\end{array} \\
61\end{array}$} & \multirow{2}{*}{$\begin{array}{c}\text { No. } \\
85\end{array}$} & \multirow{2}{*}{$\begin{array}{c}\begin{array}{c}\text { Per } \\
\text { cent. }\end{array} \\
39\end{array}$} \\
\hline U.K. & . & $\ldots$ & & & & & \\
\hline Eire & . & $\ldots$ & 1 & 5 & 7 & 13 & 6 \\
\hline \multicolumn{2}{|c|}{ West Indies } & . & 4 & 25 & 56 & 85 & 39 \\
\hline \multicolumn{2}{|c|}{ West Africa } & $\ldots$ & - & 1 & 11 & 12 & 5 \\
\hline Other & $\ldots$ & $\ldots$ & - & 6 & 18 & 24 & 11 \\
\hline Total & $\ldots$ & $\ldots$ & 6 & 60 & 153 & 219 & 100 \\
\hline
\end{tabular}

Table VIII shows that in 1961 the percentage of "repeaters" was lowest in the youngest age group for all nationalities except the West Indian; that for all nationalities there was little difference between the 20 to 24-year group and those aged 25 and over, that U.K. patients had the smallest proportion of "repeaters", and that West Indians had the highest proportion.

The more accurate recording of re-infection in Manchester since 1955, and particularly since 1951 , is therefore a not insignificant factor in the reported increase in male infections with gonorrhoea. This factor becomes even more significant in relation to long-ranging surveys (e.g. Prebble, 1962; Watt, 1961), because re-infection was seldom recorded statistically in pre-penicillin days.

Size of Male Population at Risk.-The results of the 1961 Census are not yet available and the estimates of population rest on data from the 1951 Census adjusted annually in the light of deaths and births. These estimates make no allowance for immigration into the area since 1951. There have also been outgoing shifts of population due to slum clearance and other factors. Thus no realistic comparison of changes in the population at risk between 1951 and 1961 is possible, and, moreover, the V.D. clinics in the City of Manchester also serve large population groups from neighbouring urban areas.

Age Groups.-Compulsory national service was introduced in the United Kingdom in 1939. Postponement of national service, which officially fell due at the eighteenth birthday, was granted in certain circumstances and thus some males were in their early twenties during their national service. Thus, even since the end of the war in 1945, a large proportion of males born in the U.K. were in the armed services during their late 'teens and early twenties and venereal infections contracted by such men did not appear in the statistics of civilian clinics. Even before conscription ended recently, the intake

TABLE VIII

ST. LUKE'S CLINIC, MANCHESTER. MALE GONORRHOEA "REPEATERS" BY COUNTRY OF ORIGIN AND AGE GROUP (PERCENTAGES)

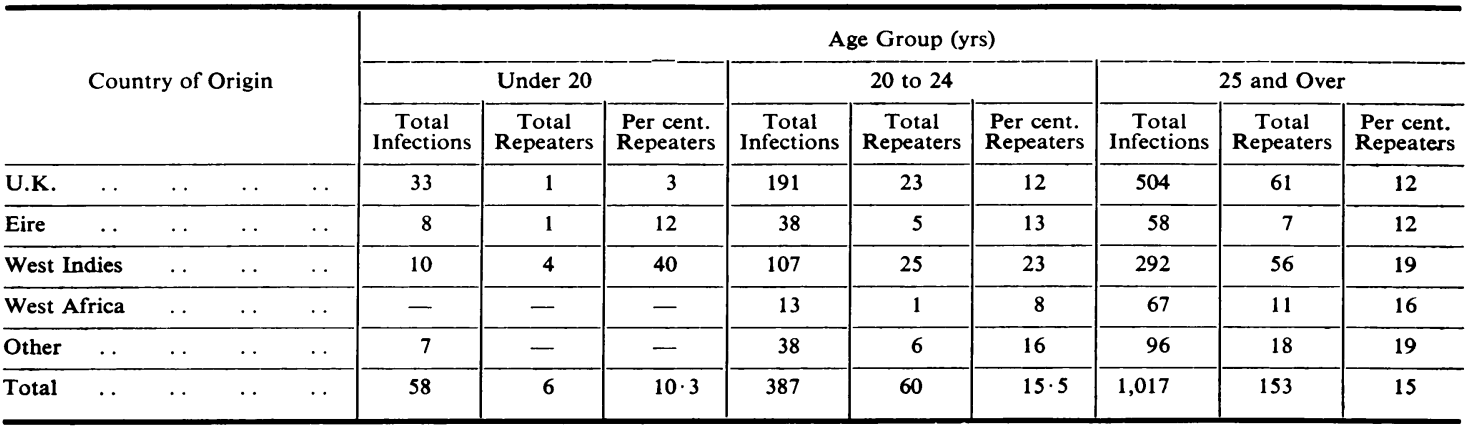


had been running down and thus the proportion of U.K. males from age 18 to the early twenties remaining in civilian life has increased in the past few years. In spite of this increase in the population at risk, there has been no increase in cases among U.K. males aged 20 to 24 years (Table III), and the increase in the actual numbers of cases in those aged 18 and 19 years is not alarming (13 cases in 1951,15 cases in 1955, 49 cases in 1959, and 31 cases in 1961).

Country of Origin.-The City of Manchester is a large industrial, business, and educational centre and always has a floating population of foreign residents from many countries. In recent years, young men from Asia, the Middle East, and certain Mediterranean countries have attended the Manchester V.D. clinics in significant numbers. The high level of employment and good wages for labourers, particularly in the building industry, have also attracted young men from Eire and they have provided an increasing proportion of gonorrhoea cases in the younger age groups (Table IV).

Negroes born in West Africa form another racial group amongst the clinic patients; they are usually aged over 20 years, and in recent years have contributed an increasing proportion of patients in the 20 to 24-year group (Table IV). The West African is prone to "repeat" infections (Table VIII).

Immigrants from the British West Indies clearly make a disproportionately large contribution to the total gonorrhoea infections treated in the Manchester clinics (Table IV). In Manchester, the increase in West Indian male immigrants started about 1954, but became more rapid since 1955 (Table IV). This pattern is similar to that found in other areas in which West Indian immigrants have congregated, e.g. in Birmingham and London (British Cooperative Clinical Group, 1960 Gonorrhoea Study). In Manchester, West Indian male patients in 1961 had more "repeat" infections than any other overseas group and their numbers equalled those of U.K.born citizens, being particularly prominent in the younger age groups.

The exact numbers of these various nationals residing in Manchester are not known, but it is clear that they make disproportionately large contributions to the total number of gonorrhoea infections treated in the Manchester clinics.

The increased rate of immigration is shown, since 1957 , by the following figures released on December 1, 1961 (Daily Telegraph, Dec. 2, 1961, p. 16), and the inflow has since accelerated in anticipation of the Commonwealth Immigrants Bill becoming law:

\begin{tabular}{|c|c|c|c|c|c|}
\hline $\begin{array}{c}\text { Country of } \\
\text { Origin }\end{array}$ & 1957 & 1958 & 1959 & 1960 & $\begin{array}{c}1961 \text { (1st } \\
10 \text { months) }\end{array}$ \\
\hline $\begin{array}{ll}\text { India } & \ldots \\
\text { Pakistan } & \cdots \\
\text { W. Indies } & \cdots \\
\text { E. Africa } & \cdots \\
\text { W. Africa } & \ldots\end{array}$ & $\begin{array}{r}6,600 \\
5,200 \\
23,000 \\
650 \\
2,200\end{array}$ & $\begin{array}{r}6,200 \\
4,700 \\
15,000 \\
400 \\
1,000\end{array}$ & $\begin{array}{r}2,900 \\
900 \\
16,400 \\
150 \\
750\end{array}$ & $\begin{array}{r}5,800 \\
2,500 \\
49,700 \\
250 \\
550\end{array}$ & $\begin{array}{r}18,300 \\
19,300 \\
57,700 \\
2,300 \\
5,100\end{array}$ \\
\hline
\end{tabular}

The social and ethnic reasons for the high gonorrhoea rates among these people have been discussed elsewhere (Laird and Morton, 1959).

Conclusions.-In Manchester, the following conclusions may be drawn:

(a) There is no evidence that gonorrhoea infections in men born in the United Kingdom have increased since 1955; the number of infections diagnosed in 1961 was only 70 per cent. of the 1951 total.

(b) Except for teenagers, the increase recorded since 1955 is confined to immigrants and those from the West Indies have increasingly made the major contribution.

(c) Since 1955, the increase in the number of infections in U.K. males aged 18 and 19 years has been small, and some of this is probably artificial, being due to the run-down of national service in recent years. The number of U.K. teenage males treated in 1961 (39) was less than that in 1959 (59).

(d) Male "repeaters" are a significant factor in the overall increase, and here again, immigrants, and especially West Indians, make a major contribution.

Case Finding.-The male with gonorrhoea has definite symptoms which cause him to seek treatment without delay. In contrast, the female with uncomplicated gonorrhoea is often asymptomatic and, being unaware of her infection, seldom has reason to seek treatment on her own initiative. Thus many women with gonorrhoea come to the clinic on the advice of the male consort infected by them; of the $\mathbf{4 0 5}$ female cases of gonorrhoea diagnosed during 1961 at St. Luke's Clinic, Manchester, 122 (30 per cent.) presented with contact slips (Nicol, 1954) issued to their male consorts; another 134 (33 per cent.) reported on the advice of the male consort but without producing a contact slip; and only 149 (37 per cent.) came to the clinic either on their own initiative or through some other agency. As it is probable that some women are too embarrassed to produce the contact slip or to admit that their male partner has told them to attend, it appears that less than one-third of female cases of gonorrhoea come to the clinic on account of symptoms alone.

The number of women attending for examination will thus be influenced by the case-finding vigour and 
persuasion of the doctor seeing the male patients; the more male patients the more contact slips and therefore the more females persuaded to attend for diagnosis. The better the man knows his female consort the more likely she is to receive the contact slip; the casual pick-up and the prostitute will seldom be sought out by the infected male and is therefore much less likely to come for treatment (Haworth and Nicol, 1954). The "reservoir" of gonorrhoea infection is thus largely created and maintained in the larger towns by intercourse between strangers or very casual acquaintances, and in these circumstances the infected male is unable to assist in bringing the infectious female to treatment. Certain streets, public houses, clubs, and coffee bars provide the meeting place which leads to such casual exposures (Laird, 1958). In Manchester, since 1955, clubs for various racial groups have multiplied and contact-tracing of the girls "picked up" in them has proved almost impossible.

The contact-slip method of case-finding was brought into general use in the Manchester clinics about 1951 but has been applied more vigorously since 1955. The services of a full-time social worker have been increasingly developed since 1956. At St. Luke's Clinic, a change of medical personnel in the female clinic in 1956 has improved its service and "atmosphere", and the efficacy of the gonococcal culture service was increased in 1959. With these changes and the epidemiological effort pursued during a period of rising incidence of male infection, it is not surprising that more infections have been diagnosed in the female (Table I) in Manchester. That case-finding has been improved in recent years is also suggested by the ratio of male to female cases diagnosed in the clinics of the City of Manchester (Table IX); this ratio improved from 5.1 in 1951 to $3 \cdot 7$ in 1955 and to $3 \cdot 3$ in 1961 . Table IX also shows that the major improvement in case-finding that took place in St. Luke's Clinic between 1951 and 1955 has been sustained and in fact increased in the last 6 years.

In comparing the increased annual figures for females in Manchester for 1959 and 1961 with the figures for 1955 and especially for 1951, some allowance for better case-finding must be made. Failure to do so would introduce a fallacy and the further back in time the comparison is made, the greater this fallacy may become.

Diagnosis.-This is often difficult in the female and must lean heavily on the result of cultures. A positive diagnosis may be made immediately when smears reveal intracellular Gram-negative diplococci, but this usually only occurs in the recentlyinfected woman. Where infection is of longer standing, clinical findings and smears are often negative and diagnosis must await the culture reports. To exclude gonococcal infection in the female, time and repeated examinations, including cultures, are essential.

"Epidemiologic Treatment".--These technical difficulties and the fact that many women will not re-attend for further tests have led to the concept of "epidemiologic treatment" whereby the female consorts of men known to have gonorrhoea are given penicillin at the first visit, even though the smears are negative and the results of cultures are still awaited. With only a few exceptions, such "epidemiologic treatment" has been used in the female clinics of the City of Manchester during the past 5 years. However, in such cases, gonorrhoea is diagnosed only if cultures prove positive; otherwise they are included under "other conditions requiring treatment". Some of these female consorts classified under "other conditions requiring treatment" might have been diagnosed as cases of gonorrhoea if treatment had been withheld whilst bacteriological tests were repeated. At St. Luke's Clinic, Manchester, in 1961, 157 women presented contact slips issued to their male consorts who had gonorrhoea; $122(77 \cdot 7$ per cent.) of these 157 women were proved to have gonorrhoea, while in the other $35(22 \cdot 3$ per cent.) the one examination before "epidemiologic treatment" failed to show positive evidence of gonorrhoea.

As a result of the practice of "epidemiologic treatment" of the female consorts of men known to

TABLE IX

RATIO OF MALE TO FEMALE GONORRHOEA INFECTIONS IN CITY OF MANCHESTER CLINICS, 1951-61

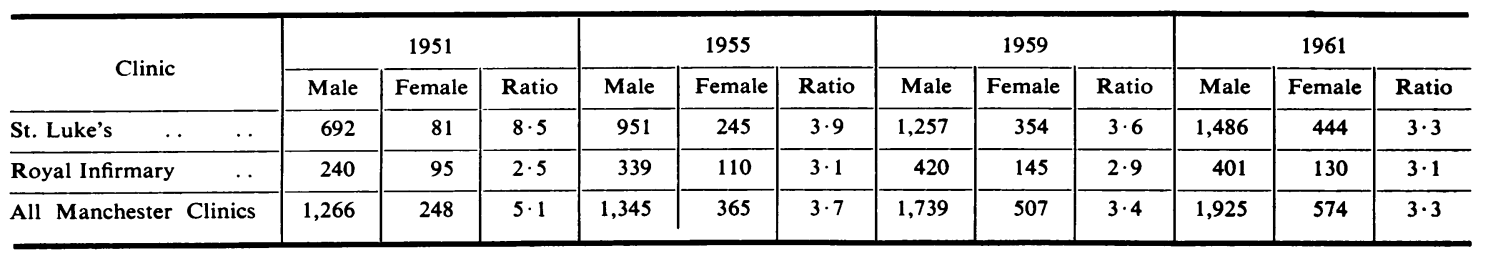


have gonorrhoea, it is quite probable that the increase since 1955 in gonorrhoea in females is actually larger than the figures suggest (Tables I and V). Table X shows, for St. Luke's Clinic, Manchester, that since 1955, figures for "other conditions requiring treatment" have increased quite as much as those for gonorrhoea. The total of 387 in 1961 for gonorrhoea is 71 per cent. more than the 226 in 1955 , while the 256 "other conditions requiring treatment" in 1961 is 95 per cent. more than the 131 in 1955.

TABLE X

ST. LUKE'S CLINIC

DIAGNOSIS IN ALL FEMALES AGED 14 YEARS AND OVER, 1951-61

\begin{tabular}{|c|c|c|c|c|c|}
\hline \multicolumn{2}{|c|}{ Diagnosis } & 1951 & 1955 & 1959 & 1961 \\
\hline Gonorrhoea & . & 84 & 226 & 309 & 387 \\
\hline $\begin{array}{l}\text { Other Condi } \\
\text { Treatment }\end{array}$ & $\begin{array}{l}\text { requiring } \\
\ldots\end{array}$ & 71 & 131 & 174 & 256 \\
\hline Total & . $\quad \ldots$ & 155 & 357 & 483 & 643 \\
\hline
\end{tabular}

Repeat Infections.-This seems a minor feature of gonorrhoea in the female as compared with the male "repeaters". At St. Luke's Clinic, Manchester, in 1961, of the 388 women treated for gonorrhoea, 27 (6.9 per cent.) returned in the same calendar year with 56 re-infections. In 1959, the "repeater" rate in females was $8 \cdot 3$ per cent.

The diagnosis of re-infection in the female is more difficult than in the male because of the absence of specific symptoms, the varying infectiousness of chronic gonorrhoea in the female, the understandable reticence in admitting further exposure and the common failure to return for post-treatment tests. Infection with strains of gonococcus less sensitive to penicillin is another recent development which further complicates the distinction between treatment failure and re-infection. It is probable that reinfection in the female occurs more often than the above rates suggest.

Teenagers.-The age grouping of female patients with gonorrhoea seen in the clinics of the City of Manchester (Table V) shows that:

(a) There has been an increase in all age groups between 1955 and 1961.

(b) This increase is small (18.6 per cent.) in patients aged 25 years and over, moderate ( 73.7 per cent.) in those aged 20-24 years, and very marked (186 per cent.) in the teenage group.

(c) In 1959 and 1961, for the first time, a small number of girls aged 14,15 , and 16 years were treated for gonorrhoea.
As it has been suggested above that the use of "epidemiologic treatment" might result in some cases of gonorrhoea being classified under "other conditions requiring treatment" ("O" cases), the figures for St. Luke's Clinic, Manchester, for teenagers in these two diagnostic categories are presented in Table XI.

TABLE XI

ST. LUKE'S CLINIC

DIAGNOSIS IN FEMALES AGED 14 TO 19 YEARS INCLUSIVE

\begin{tabular}{|c|c|c|c|c|c|}
\hline \multicolumn{2}{|c|}{ Diagnosis } & 1951 & 1955 & 1959 & 1961 \\
\hline Gonorrhoea & . & 9 & 23 & 69 & 100 \\
\hline \multicolumn{2}{|c|}{$\begin{array}{c}\text { Other Conditions requiring } \\
\text { Treatment }\end{array}$} & 8 & 19 & 37 & 49 \\
\hline Total & $\ldots$ & 17 & 42 & 106 & 149 \\
\hline
\end{tabular}

This shows that there has also been a marked increase in teenage patients in this other diagnostic category. No such relative increase of teenage cases has occurred in patients classified as "conditions not requiring treatment" (Table XII).

\section{TABLE XII}

ST. LUKE'S CLINIC

CONDITIONS NOT REQUIRING TREATMENT, IN FEMALES, EXCLUDING FAMILY CONTACTS, EXPECTANT MOTHERS, ETC., 1951-61

\begin{tabular}{c|c|c|c|c|c|c|c|c}
\hline $\begin{array}{c}\text { Age } \\
\text { Group } \\
\text { (yrs) }\end{array}$ & \multicolumn{2}{|c|}{1951} & \multicolumn{2}{|c|}{1955} & \multicolumn{2}{|c|}{1959} & \multicolumn{2}{|c}{1961} \\
\hline & No. & $\begin{array}{c}\text { Per } \\
\text { cent. }\end{array}$ & No. & $\begin{array}{c}\text { Per } \\
\text { cent. }\end{array}$ & No. & $\begin{array}{c}\text { Per } \\
\text { cent. }\end{array}$ & No. & $\begin{array}{c}\text { Per } \\
\text { cent. }\end{array}$ \\
\hline $14-19$ & 5 & $15 \cdot 6$ & 5 & $13 \cdot 9$ & 11 & $16 \cdot 4$ & 15 & $14 \cdot 6$ \\
\hline $\begin{array}{c}14 \text { and } \\
\text { Over }\end{array}$ & 32 & 100 & 36 & 100 & 67 & 100 & 103 & 100 \\
\hline
\end{tabular}

The figures (" $P_{1}$ " cases) shown in Table XII relate only to patients attending on their own initiative and exclude other cases in the same diagnostic category (e.g. family contacts of syphilitic parents or siblings, expectant mothers requiring tests for the exclusion of infection, etc.) whose attendance at the clinic was not spontaneous. Tables XI and XII refer only to St. Luke's Clinic, the busiest V.D. clinic in Manchester, but the same pattern emerges from the total figures of all the clinics in the City of Manchester (Table XIII, opposite).

The reasons given by teenage girls, found to have gonorrhoea, for their attendance at St. Luke's Clinic, Manchester, are shown in Table XIV. In 1961, only four (4 per cent.) attended solely on account of symptoms (usually Bartholinian abscess), 57 produced a contact slip, and a further eighteen came on the advice of an unidentified male consort. It is 
TABLE XIII

ALL MANCHESTER CLINICS DIAGNOSIS IN TEENAGE FEMALES

\begin{tabular}{|c|c|c|c|c|c|c|c|c|}
\hline \multirow{2}{*}{ Diagnosis } & \multicolumn{2}{|c|}{1951} & \multicolumn{2}{|c|}{1955} & \multicolumn{2}{|c|}{1959} & \multicolumn{2}{|c|}{1961} \\
\hline & No. & $\begin{array}{c}\text { Per } \\
\text { cent. }\end{array}$ & No. & $\begin{array}{l}\text { Per } \\
\text { cent. }\end{array}$ & No. & $\begin{array}{c}\text { Per } \\
\text { cent. }\end{array}$ & No. & $\begin{array}{l}\text { Per } \\
\text { cent. }\end{array}$ \\
\hline $\begin{array}{l}\text { Early } \\
\text { Syphilis .. }\end{array}$ & 5 & $4 \cdot 1$ & 1 & $1 \cdot 6$ & 1 & 0.6 & - & - \\
\hline Gonorrhoea & 41 & $34 \cdot 8$ & 31 & $41 \cdot 9$ & 101 & $60 \cdot 5$ & 126 & $55 \cdot 0$ \\
\hline "O" Cases & 32 & $27 \cdot 1$ & 35 & $47 \cdot 3$ & 48 & $28 \cdot 7$ & 79 & $34 \cdot 5$ \\
\hline$P_{1}$ Cases $\ldots$ & 40 & $33 \cdot 0$ & 7 & $9 \cdot 2$ & 17 & $10 \cdot 2$ & 24 & $10 \cdot 5$ \\
\hline Total & 118 & 100 & 74 & 100 & 167 & 100 & 229 & 100 \\
\hline
\end{tabular}

probable that some of these classified under the heading "other" failed to admit that they attended on the advice of the male partner. Table XIV shows clearly the relatively large increase in teenage girls with gonorrhoea, but also indicates that a proportion of the increase, as already suggested above, seems to be related to the increased number of infected males advising their female consorts to seek treatment.

It would be of interest to ascertain the country of origin of the male partners of the female teenagers with gonorrhoea. A truthful answer in all cases is unlikely, but it was possible to get accurate information about the male partner of those girls who presented with contact slips (Table XV). It must again be pointed out that a proportion of females attending because of a contact slip either destroy the slip or fail to produce it, and it may be that this is more likely to occur when the male partner is coloured. The figures (Table XV) indicate that the male consorts of about half the teenagers found to have gonorrhoea were born outside the United Kingdom. These racial proportions are very similar to those of all male gonorrhoea cases seen in the clinics of the City of Manchester, and one may tentatively conclude that the female teenager does not differ in this respect from the females in the older age groups.

Country of Origin.-Before 1960, female patients with gonorrhoea seen in the clinics of the City of Manchester had, with a very occasional exception, all been born in the United Kingdom. Watt (1961), in a study of venereal infections in adolescents seen at St. Luke's Clinic, Manchester in 1960, found that all

TABLE XIV

ST. LUKE'S CLINIC. TEENAGE FEMALES WITH GONORRHOEA. REASON FOR ATTENDANCE

\begin{tabular}{|c|c|c|c|c|c|c|c|c|c|c|c|c|c|c|c|c|}
\hline \multirow[b]{2}{*}{ Age (yrs) } & \multicolumn{4}{|c|}{1951} & \multicolumn{4}{|c|}{1955} & \multicolumn{4}{|c|}{1959} & \multicolumn{4}{|c|}{1961} \\
\hline & $\begin{array}{l}\text { Symp- } \\
\text { toms }\end{array}$ & $\begin{array}{c}\text { Un- } \\
\text { known } \\
\text { Con- } \\
\text { sort }\end{array}$ & $\begin{array}{l}\text { Con- } \\
\text { tact } \\
\text { Slip }\end{array}$ & Other & $\begin{array}{l}\text { Symp- } \\
\text { toms }\end{array}$ & $\begin{array}{c}\text { Un- } \\
\text { known } \\
\text { Con- } \\
\text { sort }\end{array}$ & $\begin{array}{l}\text { Con- } \\
\text { tact } \\
\text { Slip }\end{array}$ & Other & $\begin{array}{l}\text { Symp- } \\
\text { toms }\end{array}$ & $\begin{array}{c}\text { Un- } \\
\text { known } \\
\text { Con- } \\
\text { sort }\end{array}$ & $\begin{array}{l}\text { Con- } \\
\text { tact } \\
\text { Slip }\end{array}$ & Other & $\begin{array}{l}\text { Symp- } \\
\text { toms }\end{array}$ & $\begin{array}{c}\text { Un- } \\
\text { known } \\
\text { Con- } \\
\text { sort }\end{array}$ & $\begin{array}{l}\text { Con- } \\
\text { tact } \\
\text { Slip }\end{array}$ & Other \\
\hline 14 & - & - & - & - & - & - & - & - & - & - & - & - & - & - & 1 & 2 \\
\hline 15 & - & - & - & - & - & - & - & - & - & - & - & - & - & - & - & - \\
\hline 16 & - & - & - & - & - & - & - & - & - & - & 3 & 3 & - & 1 & 5 & 2 \\
\hline 17 & - & 2 & - & - & - & - & - & - & - & 4 & 7 & 3 & 1 & 4 & 9 & 5 \\
\hline 18 & 1 & 1 & 1 & - & - & 2 & 2 & 3 & 1 & - & 14 & 4 & 1 & 6 & 15 & 5 \\
\hline 19 & - & 1 & 3 & - & - & 4 & 6 & 5 & 1 & 5 & 15 & 8 & 2 & 7 & 27 & 7 \\
\hline Total & 1 & 4 & 4 & - & - & 6 & 8 & 8 & 2 & 9 & 39 & 18 & 4 & 18 & 57 & 21 \\
\hline
\end{tabular}

TABLE XV

ST. LUKE'S CLINIC. COUNTRY OF ORIGIN OF MALE REFERRING TEENAGE FEMALE WITH GONORRHOEA

\begin{tabular}{|c|c|c|c|c|c|c|c|c|c|c|c|c|}
\hline \multirow{2}{*}{ Age (yrs) } & \multicolumn{4}{|c|}{1955} & \multicolumn{4}{|c|}{1959} & \multicolumn{4}{|c|}{1961} \\
\hline & U.K. & Eire & Negro & Other & U.K. & Eire & Negro & Other & U.K. & Eire & Negro & Other \\
\hline 16 & - & - & - & - & 3 & - & 一 & - & 2 & 2 & - & 1 \\
\hline 17 & - & - & - & - & 3 & - & - & 2 & 4 & 2 & 2 & - \\
\hline 18 & 2 & - & - & 1 & 4 & 1 & 5 & 2 & 9 & - & 4 & 2 \\
\hline 19 & 4 & - & 3 & 2 & 5 & - & 7 & 2 & 14 & - & 11 & 1 \\
\hline Totals & 6 & - & 3 & 3 & 15 & 1 & 12 & 6 & 29 & 4 & 17 & 4 \\
\hline
\end{tabular}


but four of 78 infections occurred in girls born in the U.K.; the four exceptions were citizens of Eire and there were no coloured immigrants.

In 1961, immigrants were beginning to form a small proportion of the female cases of gonorrhoea (Table XVI) and this trend continues. These immigrants come from Eire or the British West Indies, and it is probable that numbers from the latter will increase.

TABLE XVI

COUNTRY OF BIRTH OF FEMALE GONORRHOEA PATIENTS IN 1961

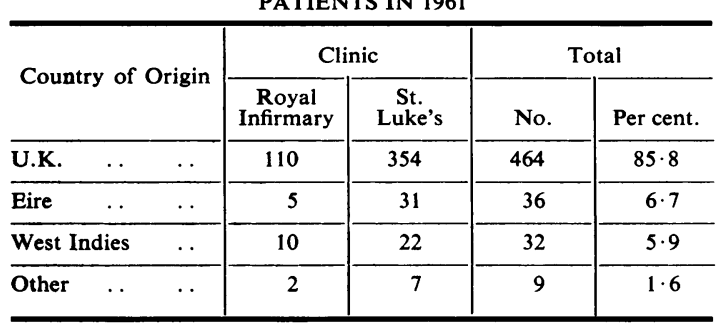

Conclusions.-In Manchester the following conclusions may be drawn:

(a) Gonorrhoea infection has increased since 1955 in females below the age of 25 years and this increase is proportionately greater in teenagers.

(b) As the absolute numbers were still greater in 1961 than in 1959, there is no evidence to suggest that this rising trend is abating.

(c) Some of the increase is due to better case-finding and improved diagnosis.

(d) The increase may be greater than the figures indicate because the use of "epidemiologic treatment" leads to some cases of gonorrhoea being classified under "other conditions requiring treatment".

(e) "Repeat" infections, although more difficult to determine in the female, are probably less common than in male patients.

$(f)$ Although female immigrants from Eire and the West Indies have attended with gonorrhoea in 1961 and their proportions are still small, this new development could have significance in the years ahead.

\section{The Future}

This study suggests that during the next decade at least two factors will be highly significant for the V.D. clinics of the City of Manchester; first, the rate at which immigration affects the already considerable immigrant group in the local population, and, secondly, the sexual behaviour of the local females entering the teenage and 20 to 24-year groups during the decade.

Immigration will be influenced by economic and political developments which are impossible to forecast. The Commonwealth Immigrants Act, which has come into operation in July, 1962, may even out the irregular rates of immigration of the past 7 years but will not necessarily reduce or even limit the present size of this section of the local population. It will specifically have no effect on immigration from Eire, which will be sensitive to economic factors and the demand for labour.

Increasing numbers of children of Jamaican and mixed parentage are being born in Manchester and their pattern of sexual behaviour will be an important influence from the mid-1970s onwards. Will they adopt the less active sexual pattern of their new country or follow that of their fathers? Further efforts seem desirable to improve the integration of coloured immigrants and their children, either into the local population or at least into responsible communities within that population.

The numbers of U.K.-born girls in the 16 to 24-year group will increase during the next decade because of the higher birth rate of the post-war period. This may, but will not necessarily, produce more cases of venereal disease in the future. While it seems definite that the number of gonorrhoeal infections in females of teenage and the early twenties has increased in the last few years and at present seems to be continuing to increase, the actual numbers are still neither large nor alarming. It seems clear that some of this upward trend is related to immigration (Table XV) and better control of entrance by these girls to clubs for coloured immigrants is desirable. More public education about venereal disease is needed and should be concentrated on the teenage group.

The largely asymptomatic nature of gonorrhoea in the female and the impossibility of quickly bringing the infected woman to treatment by contact tracing, result in the maintenance of a perpetual "reservoir" of gonorrhoeal infection in a small promiscuous section of the female population of the large cities. The control of gonorrhoea in the epidemiologic sense is still not in sight and its future incidence depends on several non-medical factors, of which the most fundamental remains the integrity of family life and sound parental influence in the home.

\section{Summary and Conclusions}

The results of a study of the age and country of origin of gonorrhoea patients attending the venereal 
disease clinics of the City of Manchester in the years 1951, 1955, 1959, and 1961, are reported.

In the male, gonorrhoea infections were more numerous in all age groups in 1959 and 1961 than in 1951 and 1955, but the increase was relatively greater in those under 25 years of age.

Infections in males born in the United Kingdom have not increased since 1955, and the 1961 total was only 70 per cent. of that of 1951 .

Infections in male teenagers born in the United Kingdom have increased since 1955 , but the numbers are still small and are not rising (59 in 1959, 39 in 1961).

Except for teenagers, the increase in male infections since 1955 has been confined to immigrants, amongst whom West Indians predominate.

Male "repeaters" are a significant factor in the overall increase, and here again, immigrants, especially West Indians, have made the major contribution.

In the female, gonorrhoea infections increased in all age groups between 1955 and 1961. The increase was small ( 18.6 per cent.) in those aged 25 years and over, moderate ( 73.7 per cent.) in those aged 20 to 24 years, and very marked (186 per cent.) in teenagers. As the total numbers were greater in 1961 than in 1959 there is no evidence that this rising trend is abating.

Some part of the increase since 1951 and 1955 may be due to better case-finding and improved diagnosis. On the other hand, the increase may be greater than the figures indicate, because the use of "epidemiologic treatment" leads to some cases of gonorrhoea being classified in another diagnostic category.

There was evidence that the male consorts of about half the teenage girls found to have gonorrhoea were immigrants.

"Repeat" infections in the female appear to be less numerous than in the male.

During the next 10 to 15 years the gonorrhoea case-load in the venereal disease clinics of the City of Manchester will be significantly influenced by two major factors: the rate at which further immigration affects the already considerable immigrant section of the local population; and the sexual behaviour of the local females who enter the teenage and 20 to 24-year groups during the next decade.

The control of gonorrhoea in the epidemiologic sense is still not in sight, and its future incidence depends largely on non-medical factors, of which the most fundamental are the integrity of family life and sound parental influence in the home.

\section{REFERENCES}

British Cooperative Clinical Group (1962). Brit. J. vener. Dis., 38, 1.

Gjessing, H. C., and Ödegaard, K. (1962). Ibid., 38, 26. Haworth, M. C., and Nicol, C. S. (1954). Ibid., 30, 36.

Laird, S. M. (1958). Ibid., 34, 137. (1961). Ibid., 37, 70 .

and Morton, R. S. (1959). Ibid., 35, 187.

Ministry of Health (1960) "Report of the Chief Medical Officer." Cmnd. 1550 (Brit. J. vener. Dis. (1962), 38,43 ).

Nicol, C. S. (1954). Ibid., 30, 171.

Prebble, E. E. (1962). Ibid., 38, 86.

Watt, L. (1961). Brit. med. J., 2, 858.

\section{La blennorragie à Manchester, 1951-61}

\section{RÉSUMÉ}

(1) On a étudié l'âge et le pays d'origine des malades atteints de blennorragie qui se présentèrent aux cliniques vénériennes de Manchester en 1951, 1955, 1959, et 1961.

(2) Chez les hommes les infections gonococciques furent plus nombreuses en 1959 et 1961 qu'en 1951 et 1955 , et l'augmentation fut plus grande chez les jeunes hommes de moins de 25 ans.

Parmi les hommes nés au Royaume-Uni le nombre des infections n'a pas augmenté depuis 1955, et le total de 1961 n'était que $70 \%$ de celui de 1951 . Cependant le nombre d'infections chez les jeunes hommes de moins de 20 ans a augmenté depuis 1955, mais les totaux sont encore bas et n'augmentent plus (59 en 1959, 39 en 1961).

Sauf parmi les jeunes gens, l'augmentation des infections gonococciques a été limitée aux immigrants, surtout ceux des Indes Occidentales.

Les hommes qui "récidivent" sont en grande partie responsables de l'augmentation de ces infections, et les immigrants, surtout ceux des Indes Occidentales, forment une partie importante de ce groupe.

(3) Chez les femmes de tout âge le nombre des infections augmenta entre 1955 et 1961 . L'augmentation fut faible $(18,6 \%)$ chez les femmes de 25 ans et au-dessus, moyenne $(73,7 \%)$ chez celles de 20 à 24 ans, et très forte $(186 \%)$ chez celles de moins de 20 ans. Puisque le nombre des infections fut plus grand en 1961 qu'en 1959 , il est indiscutable que cette augmentation chez les jeunes femmes continue toujours.

(4) Il se peut qu'une partie de l'augmentation constatée chez les deux sexes depuis 1951 et 1955 soit due au diagnostic moderne et aux méthodes plus efficaces de dépister les consorts sexuels. Mais il faut admettre que le niveau actuel peut bien être beaucoup plus élevé, parce que le "traitement épidémiologique" cache quelquefois l'infection gonococcique.

La moitié des jeunes filles de moins de 20 ans trouvèrent leurs consorts sexuels parmi les immigrants.

Les infections récidives chez les femmes furent moins nombreuses que chez les hommes. 
(5) Deux influences porteront sur le taux futur de la blennorragie dans les cliniques anti-vénériennes de Manchester: la mesure de l'immigration et la conduite sexuelle des jeunes filles qui attiendront l'âge de 13 à 24 ans pendant la prochaine décade.
Le contrôle épidémiologique de la blennorragie est encore hors de la portée du service sanitaire, et son incidence future dépendra des facteurs non-médicauxsurtout de l'intégrité de la vie familiale et de l'influence du foyer paternel. 